\title{
Determination of Maintenance Energy Requirements for Fattening Castrated Korean Black Goats (Capra hircus coreanae)
}

\author{
Sang-Ho Moon ${ }^{1,+} \oplus$, Yeong Sik Yun ${ }^{2,+}$, Na Yeon Kim ${ }^{1,3}{ }^{\circledR}$, Sanguk Chung ${ }^{1}$, Qi Man Zhang ${ }^{1}$, Yujiao Tang ${ }^{4}$, \\ Sang-Hoon Lee ${ }^{5}{ }^{\oplus}$, Jinwook Lee ${ }^{5}$, Si Heung Sung ${ }^{1}$ and Mirae $\mathrm{Oh}^{1,6, *}$ \\ 1 Department of Food Science, College of Biomedical and Health Science, Konkuk University, \\ Chungju 27478, Korea; moon0204@kku.ac.kr (S.-H.M.); narziss924@hanmail.net (N.Y.K.); \\ zkzkdh53@naver.com (S.C.); zhangqiman@naver.com (Q.M.Z.); shsung@kku.ac.kr (S.H.S.) \\ 2 Institute of Livestock Environmental Management, Daejeon 34068, Korea; lucyyellow@naver.com \\ 3 Asia Pacific Ruminant Institute, Icheon 17385, Korea \\ 4 School of Bio-sciences and Food Engineering, Changchun University of Science and Technology, \\ Changchun 130600, China; yuanxi00@126.com \\ 5 Animal Genetic Resources Center, National Institute of Animal Science, RDA, Namwon 55717, Korea; \\ sanghoon@korea.kr (S.-H.L.); koreatop5@korea.kr (J.L.) \\ 6 Grassland and Forages Division, National Institute of Animal Science, RDA, Cheonan 31000, Korea \\ * Correspondence: miraeoh@korea.kr; Tel.: +82-41-580-6755; Fax: +82-41-580-6779 \\ + Co-first Author, these authors contributed equally to this work.
}

check for updates

Citation: Moon, S.-H.; Yun, Y.S.; Kim, N.Y.; Chung, S.; Zhang, Q.M.; Tang, Y.; Lee, S.-H.; Lee, J.; Sung, S.H.; Oh, $\mathrm{M}$. Determination of Maintenance Energy Requirements for Fattening Castrated Korean Black Goats (Capra hircus coreanae). Animals 2021, 11, 1543 https://doi.org/10.3390/ani11061543

Academic Editor: Cristina Castillo Rodríguez

Received: 27 April 2021

Accepted: 22 May 2021

Published: 25 May 2021

Publisher's Note: MDPI stays neutral with regard to jurisdictional claims in published maps and institutional affiliations.

Copyright: (c) 2021 by the authors. Licensee MDPI, Basel, Switzerland. This article is an open access article distributed under the terms and conditions of the Creative Commons Attribution (CC BY) license (https:// creativecommons.org/licenses/by/ $4.0 /)$.
Simple Summary: The energy required for fattening castrated Korean black goats was estimated using the correlation between metabolic energy intake per dietary body weight and average daily gain per dietary body weight. The Y-axis intercept value was the metabolic energy requirement for maintaining the lives of the fattening Korean black goats. It was calculated to be $108.76 \mathrm{kcal} / \mathrm{kg}$ $\mathrm{BW}^{0.75}\left(p<0.05, \mathrm{r}^{2}=0.6036\right)$.

Abstract: Twelve adult (10 months old) castrated Korean black goats, with an average initial body weight of $24.98 \pm 3.7 \mathrm{~kg}$, were used in this experiment to determine their maintenance energy requirements. Dry matter intakes $(\mathrm{g} / \mathrm{d}, p=0.945)$ were not affected by energy levels, but metabolic energy intake $(\mathrm{kcal} / \mathrm{d}, p<0.002)$ and average daily gain $(\mathrm{g} / \mathrm{d}, p<0.001)$ were significantly increased at higher energy levels. Nutrient digestibility was similar in the treatments, but crude fat digestibility increased with the addition of protective fat powder $(p=0.001)$. The energy required for fattening the castrated Korean black goats was estimated using the correlation between metabolic energy intake per dietary body weight and average daily gain per dietary body weight. The Y-axis intercept value was calculated to be $108.76 \mathrm{kcal} / \mathrm{kg} \mathrm{BW} \mathrm{BW}^{0.75}\left(p<0.05, \mathrm{r}^{2}=0.6036\right)$, which was the metabolic energy requirement for maintaining the lives of the fattening Korean black goats. The estimated energy requirements of the black goat can improve specification techniques, such as the energy level and the amount of feed supply required for domestic black goats.

Keywords: Korean black goat; feeding standard; energy requirements

\section{Introduction}

Profitable feeding standards need to balance livestock nutrient requirements against the financial outlay of feed purchases made by farmers within the native environment of Korea. Optimized nutrient supply is indispensable for improving productivity, and its accuracy is an index in evaluating the competitiveness of the livestock industry. Feeding standards for livestock are necessary to establish optimal livestock growth stages and determine the appropriate amount of protein, energy, and mineral matter required. Productivity factors such as meat volume are closely related to environmental factors such as purchased feed [1]. The ratio of muscle to fat in livestock differs greatly depending on the nutrient content of the feed. The energy level of the feed for livestock may affect their growth [2]. 
Moreover, it is very important to determine the amount of energy required to maintain the livestock, since $50-70 \%$ of the energy level of the feed is used by the livestock for maintenance [3]. An inadequate supply of appropriate energy is closely related to breeding problems such as reproductive impairment [4]. Therefore, it is important to understand the maintenance energy requirements for rearing livestock.

Measuring metabolism using a respiratory calorie meter, comparative massacre, and energy balance is often used to estimate nutrient requirements [5]. Recently, the availability and scalability of large amounts of comparable data have encouraged researchers to use estimation methods based on correlation between daily weight gain and indirectly accumulated energy [6,7]. The latest revision by the National Research Council (NRC) [8] has adopted a regression equation estimation method for nutrient requirements.

Korean black goats (Capra hircus coreanae) have traditionally been consumed as special food for health that helps strengthen the immune system, but this consumption style has recently changed them to common meat in Korea [2]. Consequently, Korean black goat feeding farms have upgraded their facilities for large-scale operations and with a particular specialism, and goat numbers have increased. In order to secure stable productivity during goat farming, a standard that can accurately estimate and stabilize energy and nutrient requirements at each growth stage is needed.

Unlike other ruminants, goats have a high ability to degrade the cell wall components of poor-quality feed and have physiological characteristics that often use nitrogen and water even under stressed conditions [9]. Therefore, a feeding standard for goats is necessary. However, so far Koreans have only studied nutrient requirements and feeding standards for major livestock animals such as beef cattle, dairy cattle, hens, and pigs, while other countries have goat feeding standards. The study to determine nutrient requirements of goats only began in the 1960s as they were thought to be of lower importance. A nutrient requirement profile was initiated by the NRC in 1981. However, most of the available goat feeding standards are difficult to use for the Korean black goat, as the information is unsuitable for this variety. Thus, a goat feeding standard appropriate for the Korean environment is essential [10].

In Korea, although many studies on goats have been published since 2005, only Kim et al. [11] have shown the effect of protein level difference in concentrated feed for Korean black goats on growth and feed utilization. Choi et al. [2] reported the energy requirements for the growth and meat quality of black goats. To the best of our knowledge, there are no studies that show the energy requirements for the maintenance of fattening Korean black goats. The aim of this research was to estimate the maintenance energy requirements for fattening castrated Korean black goats to help reduce feed costs for farming goats and to obtain basic data for establishing a goat feeding system using the regression equation estimation method.

\section{Materials and Methods}

\subsection{Animals and Diets}

All animal experimentation protocols were approved by the Konkuk University Institutional Animal Care and Use Committee (KU19005). Twelve adult (10 months old) castrated Korean black goats, with an average initial body weight of $24.98 \pm 3.7 \mathrm{~kg}$, were used with Latin squares in experimental design $(4 \times 4)$ to determine their maintenance energy requirements. The experiment was performed at a test farm located in Icheon City, Gyeonggi-do, from October 28 to December 30, 2016. The experiment consisted of 4 treatments (energy levels: NRC $+0 \%, \mathrm{~T} 1$; NRC $+5 \%, \mathrm{~T} 2 ; \mathrm{NRC}+10 \%, \mathrm{~T} 3 ; \mathrm{NRC}+20 \%$, T4), which were based on NRC's recommendation of $108 \mathrm{kcal}$ of body weight scaled at $75 \%$ $\left(\mathrm{BW}^{0.75}\right)$ as a maintenance energy requirement for indigenous female and wether goats in their growth stages [8]. The experimental phase consisted of a 10-day feed adaptation period and a 5-day main experiment. During the entire experimental period, the black goat was raised in an individual breeding fence capable of separating urine and feces $(1.5 \times 0.8 \mathrm{~m})$. The pen structure referred to a study by Cowan et al. [12]. Tent fabrics were 
used to maintain the inside temperature of the goat pens. During the experimental period, the experimental black goats were fed total mixed ration (TMR) feeds prepared for the treatments each at 09:00 and 17:00, and the average temperature of the total experimental period was $6.9^{\circ} \mathrm{C}$. The ingredients of the TMR are shown in Table 1 . The TMR consisted of $14 \%$ crude protein (CP), $56 \%$ total digestible nutrients (TDNs), and $1791.9 \mathrm{kcal} / \mathrm{kg}$ energy. The energy levels of the experimental feed were controlled using protected fat powder that was a high-energy additive in which hardly any $\mathrm{CP}$ or crude fiber was contained, and did not affect other ingredients. The experimental feed was offered to the goats as dry matter, set at $2.0 \%$ of the goat body weight in order to induce the intake of the entire amount of experimental feed. Water was unrestricted for the goats.

Table 1. Ingredients of the experimental total mixed ration (TMR).

\begin{tabular}{cc}
\hline Ingredients & TMR $^{\text {a }} \mathbf{( \% )}$ \\
\hline Corn gluten feed & 4.0 \\
Lupine, grounded & 2.0 \\
Yeast culture & 3.5 \\
Wheat gluten & 10.0 \\
Corn grain, grounded & 3.0 \\
Coconut kernel meal & 18.9 \\
Soybean hull pellet & 2.0 \\
Soybean meal & 3.6 \\
Limestone & 2.8 \\
Salt & 1.0 \\
Multimix vitamin & 0.3 \\
Sodium bicarbonate & 0.6 \\
Magnesium oxide & 0.3 \\
Molasses & 1.2 \\
Water & 1.5 \\
Glycerin & 0.3 \\
Alfalfa hay & 5.0 \\
Perennial ryegrass & 30.0 \\
Klein grass hay & 10 \\
Total & 100 \\
\hline aMR (total mixed ration) containing $14 \%$ crude protein, 56\% total digestible nutrients, and $1791.9 \mathrm{kcal} / \mathrm{kg}$ \\
energy.
\end{tabular}

\subsection{Measuring Body Weights and Feed Intake}

The body weights and feed intake of the black goats were measured to estimate their maintenance energy requirements during the experiment. In the initial experiment, the initial body weight was used as the measurement value, and the body weight measured at the end of each period (T1-T4) was set as the final body weight. The amount of intake of feed was estimated by subtracting the residual quantity before the next feeding from the whole amount of the first feeding.

\subsection{Sampling Procedures}

The feces of the black goats were collected and analyzed to investigate the digestibility of the samples. During the collection of manure, the total amount of manure per individual black goat was weighed and recorded. Fecal matter was collected in a plastic bag and vacuum-sealed. After each treatment, the total amount of feces samples collected per individual during the collection period was thoroughly mixed. The samples were then transferred to the laboratory, dried, and stored in an oven at $65^{\circ} \mathrm{C}$. The experimental diets (TMRs) were also dried and stored in an oven at $65^{\circ} \mathrm{C}$, and crushed to pass through a $1 \mathrm{~mm}$ screen (Thomas Scientific, Model 4, Swedesboro, NJ, USA) for further analysis. 


\subsection{Analytical Techniques}

To evaluate the feed value of the experimental diet, samples were collected during each experimental period. The results of the composition analysis of the experimental diets are shown in Table 2. The chemical compositions included dry matter (DM), crude protein $(\mathrm{CP})$, ether extract $(\mathrm{EE})$, crude fiber $(\mathrm{CF})$, and crude ash of the experimental feed samples, which were determined using the method developed by the Association of Official Analytical Chemists (AOAC) [13]. The contents of neutral detergent fiber (NDF) and acid detergent fiber (ADF) were measured according to the method described by Van Soest [14]. The apparent nutrient digestibility of the feed in goats was assessed in vivo. During the 5 days of experimental period, feed intake and fecal discharge were measured, and digestibility was determined through that of each chemical component.

Table 2. Ingredients of the experimental total mixed ration (TMR).

\begin{tabular}{cccccccc}
\hline \multirow{2}{*}{ Contents $^{1}$} & DM & CP & EE & CF & NDF & ADF & Ash \\
\cline { 2 - 6 } & \% & & & & & \\
\cline { 2 - 6 } in DM & $91.9 \pm 0.4$ & $13.7 \pm 0.8$ & $6.3 \pm 0.9$ & $37.5 \pm 0.4$ & $57.4 \pm 0.5$ & $32.5 \pm 0.9$ & $8.9 \pm 0.3$ \\
TMR & $97.9 \pm 0.1$ & $0.1 \pm 0.02$ & $95.4 \pm 0.4$ & - & - & - & $12.7 \pm 0.3$ \\
\hline
\end{tabular}

${ }^{1}$ DM: dry matter, CP: crude protein, EE: ether extract, CF: crude fiber, NDF: neutral detergent fiber, ADF: acid detergent fiber.

\subsection{Statistical Analysis}

All statistical analysis, except estimating the maintenance energy requirements, was performed by Tukey's test using SAS software 9.3 (SAS Institute, Cary, NC, USA). The analysis used a randomly extracted whole block ANOVA to compare the results of 4 treatment groups. For estimating the maintenance energy requirements, a regression analysis by using correlation between average daily gain (ADG) and metabolizable energy intake (MEI) was performed using the PROC REG method of the SAS program. All data were calibrated using metabolic weight.

\section{Results and Discussion}

\subsection{Intake and Growth of Fattening Castrated Korean Black Goats Fed with Different Metabolizable Energy Levels}

The effect of energy levels on body weight, feed intake, and ADG on fattening castrated Korean black goats is shown in Table 3. The average initial body weight in each treatment group was $25 \mathrm{~kg}$ to minimize individual factors for goat weight. The DM intake of the goats did not significantly differ among T1 $(633.0 \pm 66.3 \mathrm{~g} / \mathrm{d}), \mathrm{T} 2(647.7 \pm 62.7 \mathrm{~g} / \mathrm{d}), \mathrm{T} 3$ $(635.5 \pm 73.7 \mathrm{~g} / \mathrm{d})$, and T4 $(636.0 \pm 67.2 \mathrm{~g} / \mathrm{d})(p=0.945)$. DM intake generally depends on the type of feeds and individual characteristics of animals. According to previous studies conducted by Ranjhan [15] and Lu [16], the DM intake of the goats by grazing site in India was estimated to be between $1.47 \%$ and $3.65 \%$ of body weight. In the case of forage, DMI has been shown to decrease with higher energy levels [17]. However, reduction in DM intake of forage due to increased energy levels was considered. The energy requirements of the black goats were being met by supplementary feed. In this study, it was considered that there was no significant difference in DM intake, because the experimental goats were fed a limited amount of TMR, whose energy levels were changed to add the protective fat powder against other feed components, such as forages or concentrated feeds. The amount of the diets was induced with the intake of DM set at $2.0 \%$ of the goat body weight in order for the experimental feed to be entirely consumed by the goats, and the entire feed was consumed in all the treatments in this study. 
Table 3. Effect of energy levels on body weight and feed intake in fattening castrated Korean black goats $(n=12)$.

\begin{tabular}{|c|c|c|c|c|c|c|}
\hline \multirow{2}{*}{ Contents } & \multicolumn{4}{|c|}{ Treatments ${ }^{1}$} & \multirow{2}{*}{ SEM $^{2}$} & \multirow{2}{*}{$p$ Value ${ }^{3}$} \\
\hline & T1 & $\mathrm{T} 2$ & T3 & T4 & & \\
\hline $\begin{array}{l}\text { Initial body weight } \\
\qquad(\mathrm{kg})\end{array}$ & 25.8 & 26.5 & 25.8 & 25.9 & 0.55 & 0.959 \\
\hline $\begin{array}{l}\text { Final body weight } \\
(\mathrm{kg})\end{array}$ & 26.6 & 26.3 & 26.2 & 26.5 & 0.55 & 0.992 \\
\hline $\begin{array}{c}\text { Dry matter intake } \\
(\mathrm{g} / \mathrm{d})\end{array}$ & 633.0 & 647.7 & 635.5 & 636.0 & 2.37 & 0.945 \\
\hline $\begin{array}{c}\text { Metabolizable energy } \\
\text { intake } \\
\left(\mathrm{Kcal} / \mathrm{kg}\left(\mathrm{BW}^{0.75}\right)\right)\end{array}$ & 108.0 & 113.4 & 118.8 & 129.6 & - & - \\
\hline $\begin{array}{l}\text { Metabolizable energy } \\
\text { intake }(\mathrm{Kcal} / \mathrm{d})\end{array}$ & $1233.9^{c}$ & $1325.7^{b}$ & $1358.5^{b}$ & $1478.0^{\mathrm{a}}$ & 3.47 & $<0.002$ \\
\hline $\begin{array}{c}\text { Average daily gain } \\
(\mathrm{g} / \mathrm{d})\end{array}$ & $16.3^{c}$ & $21.2^{\mathrm{b}}$ & $29.5^{b}$ & $65.9^{a}$ & 0.96 & $<0.001$ \\
\hline 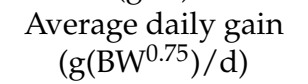 & $8.1^{c}$ & $9.8^{b}$ & $12.1^{b}$ & $22.9^{a}$ & 0.55 & $<0.001$ \\
\hline
\end{tabular}

${ }^{1} \mathrm{~T} 1: \mathrm{NRC}+0 \%, \mathrm{~T} 2: \mathrm{NRC}+5 \%, \mathrm{~T} 3: \mathrm{NRC}+10 \%, \mathrm{~T} 4: \mathrm{NRC}+20 \% .{ }^{2}$ SEM: standard error of means. ${ }^{3}$ The effect of feed intake level. ${ }^{a b c}$ Means with different superscripts within the same row are significantly different $(p<0.05)$.

We used the regression equation estimation method of the correlation between ADG and MEI [6,7]. Individual metabolism pens were used in this experiment to achieve accurate MEI measurements. The MEI per metabolic body weight of each treatment group was set to the maintenance energy requirement of growing indigenous goats as recommended by the NRC [8]. The T1 group was therefore set at $108.0 \mathrm{kcal} / \mathrm{kg} \mathrm{BW}{ }^{0.75}$. The T2 group was calculated at $+5 \%$ to $113.4 \mathrm{kcal} / \mathrm{kg} \mathrm{BW}^{0.75}$, the T3 group was calculated at $+10 \%$ to $118.8 \mathrm{kcal} / \mathrm{kg} \mathrm{BW}^{0.75}$, and the T4 group was calculated at $+20 \%$ to $129.6 \mathrm{kcal} / \mathrm{kg}$ $\mathrm{BW}^{0.75}$. MEI during the experiment was therefore between $1233.9 \pm 129.2 \mathrm{kcal} / \mathrm{d}$ and $1478.0 \pm 165.0 \mathrm{kcal} / \mathrm{d}$ for the higher energy requirement levels $(p=0.002)$. The ADG was $16.3 \pm 2.7 \mathrm{~g} / \mathrm{d}$ for T1, $21.2 \pm 8.1 \mathrm{~g} / \mathrm{d}$ for T2, $29.5 \pm 18.6 \mathrm{~g} / \mathrm{d}$ for T3, and $65.9 \pm 20.9 \mathrm{~g} / \mathrm{d}$ for $\mathrm{T} 4(p=0.001)$. These results show that the amount of ADG increased as MEI increased in the maintenance of the black goats in this study. In a similar study of Spanish goats, the metabolizable energy level of feed was 2.1-2.7 Mcal $/ \mathrm{kg}$, the ADG was 66.6-81.8 g/day [17], and the feed energy level was $2.79 \mathrm{Mcal} / \mathrm{kg}$, demonstrating a high ADG [18].

\subsection{Digestibility of Fattening Castrated Korean Black Goats Fed with Different Metabolizable Energy Levels}

The apparent nutrient digestibility in castrated black goats fed at different energy levels is shown in Table 4. The average digestibility of DM was 59.7-61.2\% in each treatment group. The TMR induced a balanced intake of forage and concentrated feeds that stabilized fermentation in the rumen and increased nutrient utilization [19,20]. Jung et al. [21] and Choi et al. [22] reported that the digestibility of TMR in black goats was $62-67 \%$. The digestibility of each treatment showed a similar tendency, and no significant difference, excluding EE digestibility, was found $(p=0.001)$. Increased DMI in ruminants may cause digestibility in the rumen to drop because of an increased rate of ruminal passage [23]. However, in this study, DM intake was similar across the treatment groups despite the metabolizable energy levels being different, and therefore, feed digestibility was not affected. The EE digestibility was $66.9 \pm 7.5 \%$ in $\mathrm{T} 1,74.0 \pm 7.9 \%$ in $\mathrm{T} 2,75.2 \pm 10.8 \%$ in $\mathrm{T} 3$, and $74.2 \pm 10.0 \%$ in T4 $(p=0.001)$ in this study. Thus, digestibility was higher in the feed supplemented with protected fat powder. The EE digestibility in this study was similar to that in a report on oil being added to a concentrated feed mixture containing 7:3 alfalfa and hay, where digestibility was $63.48 \%$ for an oil-free feed, $82.88 \%$ for a soybean oil supplement, and $82.37 \%$ for a corn oil supplement [23]. Generally, ruminant feed has a 
total fat content of $2-5 \%$. In actual specifications, when the fat content of the feed is above $5 \%$, the digestion of crude fiber in the rumen decreases. When the fat content of the feed exceeds $7-8 \%$, the rumen microbiome is altered, having a direct or indirect effect on the degrading bacteria and methanogenic bacteria. This may lead to metabolic disorders as the ruminal fermentation mechanism is changed [24-26]. In this study, we used protective fat powder, which protects the fat from dilution, degradation, and hydrogenation in the rumen. This maintains the rumen digestion and fermentation mechanism in the normal state and enhances lipase activity in the small intestine.

Table 4. Apparent nutrient digestibility in castrated black goats fed diets of different metabolizable energy requirement levels.

\begin{tabular}{ccccccc}
\hline \multirow{2}{*}{ Contents $^{\mathbf{1}}$} & \multicolumn{5}{c}{ Treatments $^{\mathbf{2}}$} & \multicolumn{2}{c}{ SEM $^{\mathbf{3}}$} & ${\text { p } \text { Value }^{\mathbf{4}}}$ \\
\cline { 2 - 5 } & T1 & T2 & T3 & T4 & & \\
\hline DM (\%) & 59.7 & 60.9 & 61.2 & 59.8 & 1.12 & 0.981 \\
CP (\% in DM) & 66.2 & 69.3 & 68.6 & 67.9 & 1.09 & 0.881 \\
EE (\% in DM) & $66.9^{\mathrm{b}}$ & $74.0^{\mathrm{a}}$ & $75.2^{\mathrm{a}}$ & $74.2^{\mathrm{a}}$ & 1.22 & 0.001 \\
CF (\% in DM) & 72.2 & 72.4 & 73.0 & 73.2 & 0.95 & 0.986 \\
NDF (\% in DM) & 60.3 & 61.1 & 62.4 & 60.9 & 1.10 & 0.966 \\
ADF (\% in DM) & 58.7 & 59.5 & 62.0 & 59.4 & 1.10 & 0.873 \\
Ash (\% in DM) & 29.2 & 28.6 & 25.3 & 29.0 & 1.38 & 0.937 \\
\hline
\end{tabular}

${ }^{1}$ DM: dry matter, CP: crude protein, EE: ether extract, CF: crude fiber, NDF: neutral detergent fiber, ADF: acid detergent fiber. ${ }^{2} \mathrm{~T} 1$ : NRC $+0 \%$, T2: NRC $+5 \%$, T3: NRC $+10 \%$, T4: NRC $+20 \% .{ }^{3}$ Standard error of means. ${ }^{4}$ The effect of feed intake level. ${ }^{\mathrm{ab}}$ Means with different superscripts within the same row are significantly different $(p<0.05)$.

\subsection{Estimation of Energy Requirements for Maintenance of Fattening Castrated Korean Black Goats}

The results of estimating the energy requirements for fattening castrated Korean black goats using the correlation between MEI per dietary body weight (Table 3, T1, $108.0 \mathrm{kcal} / \mathrm{kg}$ $\mathrm{BW}^{0.75} ; \mathrm{T} 2,113.4 \mathrm{kcal} / \mathrm{kg} \mathrm{BW}^{0.75} ; \mathrm{T} 3,118.8 \mathrm{kcal} / \mathrm{kg} \mathrm{BW}^{0.75} ; \mathrm{T} 4,129.6 \mathrm{kcal} / \mathrm{kg} \mathrm{BW}^{0.75}$ ) and ADG per dietary body weight are indicated in Figure 1. The Y-axis intercept value, which is the metabolic energy requirement for the maintenance of fattening castrated Korean black goats, was calculated at $108.76 \mathrm{kcal} / \mathrm{kg} \mathrm{BW}^{0.75}\left(p<0.05, \mathrm{r}^{2}=0.6036\right)$. The amount of energy required for maintenance varies depending on age, sex, breed, and breeding environment [8]. It is also known that, as age increases, the maintenance requirement by body size decreases [6,7]. Metabolizable energy for maintenance requirements was summarized by the NRC, which is $117 \mathrm{kcal} / \mathrm{kg} \mathrm{BW}^{0.75}$ for growing indigenous or local goats with weaning at 1.5 years of age [8]. In a past research by Prieto et al., the results of the experiment in which goats were fed Lucerne hay and mixed diet showed that energy requirements for maintenance are estimated to be $106.83 \mathrm{kcal} / \mathrm{kg} \mathrm{BW}^{0.75}$ and $105.16 \mathrm{kcal} / \mathrm{kg}$ $\mathrm{BW}^{0.75}$ [9]. Since there was no statistical significance in the Prieto experiments, they calculated a composite regression with an energy requirement of $105.88 \mathrm{kcal} / \mathrm{kg} \mathrm{BW}^{0.75}$ for maintenance [9]. However, the NRC recommends that energy requirements for the maintenance of indigenous goats should be $108 \mathrm{kcal} / \mathrm{kg} \mathrm{BW}^{0.75}$ and $101 \mathrm{kcal} / \mathrm{kg} \mathrm{BW}^{0.75}$ during growth and mature periods, respectively, for female and wether goats [8]. In Korea, where black goats are set to mature at 8 months of age, and the black goats in this experiment were 10 months old, the results of this study are similar to those of the NRC [8] for the growing stage. The difference between the energy requirement estimates from the present study and those from the study of Sahlu et al. [27] is presumably due to the number of varieties, experimental methods, and number of data points used to estimate the regression equations. In general, the estimation of nutrient requirements by regression analysis may be less accurate than that by other methods. It is difficult to know whether energy is being used for accumulation or maintenance in the body, and the effects of intestinal fullness, variety, and age may further impact interpretations. Therefore, 
Sahlu et al. [27] suggested that varieties and genetic characteristics need to be considered when estimating the energy requirements of goats.

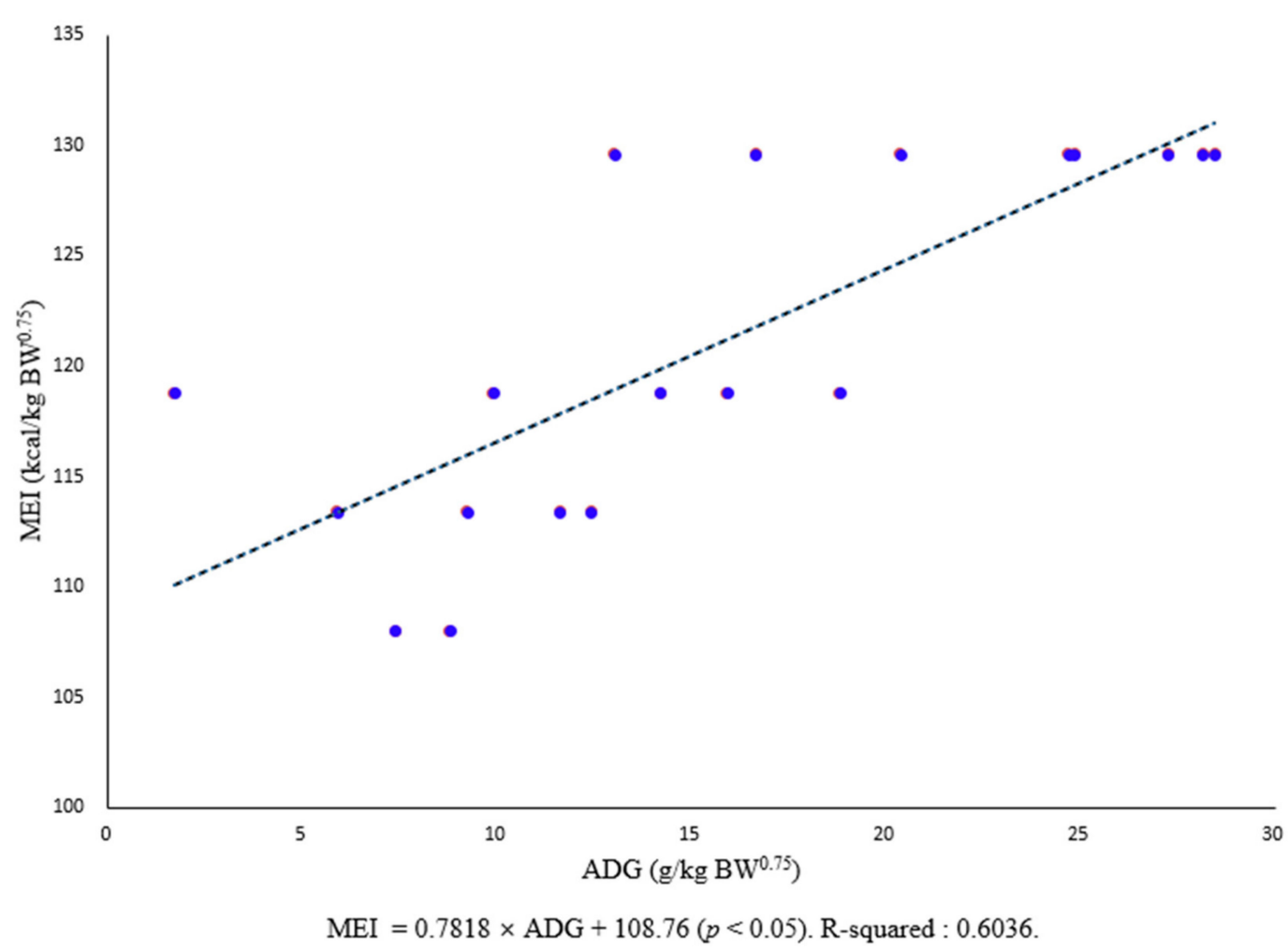

Figure 1. Relationship between metabolizable energy intake (MEI) (in Kcal/ $\mathrm{kg} \mathrm{BW}^{0.75}$ ) and average daily gain (ADG) (in $\mathrm{g} / \mathrm{kg} \mathrm{BW}^{0.75}$ ) of fattening castrated Korean black goats. Points are observed values; the line represents the regression line for all observations and describes the equation: $\mathrm{MEI}=0.7818 \times \mathrm{ADG}+108.76, \mathrm{r}^{2}=0.6036$.

Energy requirements for maintenance also differ with seasonal and temperature changes [28-30]. A previous study conducted by Salah et al. [31] determined the nutrient requirements of goats to be $108.01 \mathrm{kcal} / \mathrm{kg} \mathrm{BW}^{0.75}$ in a tropical climate and $105.90 \mathrm{kcal} / \mathrm{kg}$ $\mathrm{BW}^{0.75}$ in a temperate climate. Nutrient management depend on environmental temperature is very important. Livestock stress due to too high or low temperatures may cause reductions of feed intake. Therefore, feed should contain energy sources with high-energy utilization rates and should supply appropriate levels of energy. Small ruminants in tropical climates appear to have higher metabolizable energy requirements for maintenance compared with those in temperate climates.

\section{Conclusions}

The maintenance energy requirement was calculated to be $108.76 \mathrm{kcal} / \mathrm{kg} \mathrm{BW}^{0.75}$ in this study, which is similar to the maintenance energy requirement for a tropical environment. However, the study was carried out from October 28 to December 30, during a winter climate. Goats have higher energy requirements in winter months than in other seasons to maintain their body temperature. For weight maintenance alone, higher energy supply needs to maintain body temperature in a low-temperature environment. As a result of the study, it should be considered that the maintenance energy requirements of Korean black goats can be greatly affected in the four seasons in Korea. Additionally, it can help to prevent animal feed waste in goat farms and baseline data to establish the Korean black goat feeding system. There should be further study on maintenance energy requirements of black goats according to seasonal energy needs to establish more specific information about energy requirements for the maintenance of Korean black goats. 
Author Contributions: Conceptualization, S.-H.M., Y.S.Y. and M.O.; methodology, N.Y.K., Y.T. and S.H.S.; validation, S.-H.L. and J.L.; formal analysis, S.C. and Q.M.Z.; investigation, N.Y.K. and Y.T.; data curation, N.Y.K., S.C., Q.M.Z., Y.T., S.-H.L. and J.L.; writing-original draft preparation, S.-H.M. and Y.S.Y.; writing-review and editing, S.-H.M., S.H.S. and M.O.; project administration, S.-H.M. All authors have read and agreed to the published version of the manuscript.

Funding: This work was carried out with the support of the "Cooperative Research Program for Agriculture Science and Technology Development (PJ014239)," Rural Development Administration, Republic of Korea.

Institutional Review Board Statement: The animal care and handling protocols used in this study were approved by the Konkuk University Institutional Animal Care and Use Committee (approval code: KU19005).

Data Availability Statement: The data presented in this study are available on reasonable request from the corresponding author.

Acknowledgments: The authors acknowledge that the funder of this research work for the provision of financial needs.

Conflicts of Interest: We certify that there is no conflict of interest with any financial organization regarding the material discussed in this manuscript.

\section{References}

1. Paek, B.H.; Hong, S.G.; Kwon, E.G.; Cho, W.M.; Yoo, Y.M.; Shin, K.J. Effects of energy level of concentrate feed on meat quality and economic evaluation in finishing Hanwoo steers. J. Anim. Sci. Technol. 2005, 47, 447-456.

2. Choi, S.H.; Hwangbo, S.; Kim, S.W.; Kim, Y.K.; Sang, B.D.; Myung, J.H.; Hur, S.N.; Jo, I.H. Effects of dietary energy level on growth and meat quality of Korean black goats. J. Anim. Sci. Technol. 2007, 49, 509-514.

3. Seol, Y.J.; Kim, K.H.; Baek, Y.C.; Lee, S.C.; Ok, J.U.; Lee, K.Y.; Hong, S.K.; Jang, S.S.; Choi, C.W.; Song, M.K.; et al. Determination of maintenance energy requirements for growing Hanwoo steers. J. Anim. Sci. Technol. 2011, 53, 155-160. [CrossRef]

4. $\quad$ Almeida, A.K.; Resende, K.T.; St-Pierre, N.; Silva, S.P.; Soares, D.C.; Fernandes, M.H.M.R.; Souza, A.P.; Silva, N.C.D.; Lima, A.R.C.; Teixeira, I.A.M.A. Energy requirements for growth in male and female Saanen goats. J. Anim. Sci. 2015, 93, 3932-3940. [CrossRef] [PubMed]

5. Beever, D.E.; Cammell, S.B.; Thomas, C.; Spooner, M.C.; Haines, M.J.; Gale, D.L. The effect of date of cut and barley substitution on gain and on the efficiency of utilization of grass silage by growing cattle: 2. Nutrient supply and energy partition. Br. J. Nutr. 1988, 60, 307-319. [CrossRef] [PubMed]

6. Onwuka, C.F.I.; Akinsoyinu, A.O. Protein and energy requirements for maintenance and gain by West African Dwarf goats fed cassava (Manihot utilissima) leaves with peels as supplement. Small Rumin. Res. 1989, 2, 291-298. [CrossRef]

7. Luo, J.; Goetsch, A.L.; Sahlu, T.; Nsahlai, I.V.; Johnson, Z.B.; Moore, J.E.; Galyean, M.L.; Owens, F.N.; Ferrell, C.L. Prediction of metabolizable energy requirements for maintenance and gain of preweaning, growing and mature goats. Small Rumin. Res. 2004, 53, 231-252. [CrossRef]

8. National Research Council (NRC). Nutrient Requirements of Goats: Angora, Dairy, and Meat Goats in Temperate and Tropical Countries; National Academy Press: Washington, DC, USA, 2007; p. 66.

9. Prieto, C.; Aguilera, J.F.; Lara, L.; Fonolla, J. Protein and energy requirements for maintenance of indigenous granadina goats. Br. J. Nutr. 1990, 63, 155-163. [CrossRef]

10. Hwangbo, S. Effects of the grazing and barn feeding system on growth performance and carcass characteristics in Korean black goats. J. Agric. Life Sci. 2014, 48, 123-131. [CrossRef]

11. Kim, K.H.; Oh, Y.G.; Kim, W.; Lee, S.C.; Shin, K.J.; Jeon, B.T. Determination of energy requirements for maintenance in Hanwoo steers. J. Anim. Sci. Technol. 2004, 46, 193-200.

12. Cowan, R.L.; Hartsook, E.W.; Whelan, J.B.; Long, T.A.; Wetzel, R.S. A cage for metabolism and radio-isotope studies with deer. J. Wildl. Manag. 1969, 33, 204-208. [CrossRef]

13. Association of Official Analytical Chemists (AOAC). Official Methods of Analysis, 15th ed.; Association of Official Analytical Chemists: Washington, DC, USA, 1990; pp. 200-210.

14. Van Soest, P.J.; Robertson, J.B.; Lewis, B.A. Methods for dietary fiber, neutral detergent fiber, and nonstarch polysaccharides in relation to animal nutrition. J. Dairy Sci. 1991, 74, 3583-3597. [CrossRef]

15. Ranjhan, S.K. Animal Nutrition in the Tropics; Vikas Publication of House: New Delhi, India, 1980; p. 480.

16. Lu, C.D. Grazing behavior and diet selection of goats. Small Rumin. Res. 1988, 1, 205-216. [CrossRef]

17. Ahn, B.H.; Lee, B.O.; Kwack, J.H. Effect of Energy Levels on Performance of Korean Native Goat. Korean J. Anim. Nutr. Feed 1991, 15, 321-329.

18. Ivey, D.S.; Owens, F.N.; Sahlu, T.; The, T.H.; Claypool, P.L.; Goetsch, A.L. Growth and cashmere production by Spanish goats consuming ad libitum diets differing in protein and energy levels. Small Rumin. Res. 2000, 35, 133-139. [CrossRef] 
19. McGilliard, M.L.; Swisher, J.M.; James, R.E. Grouping lactating cows by nutritional requirements for feeding. J. Dairy Sci. 1983, 66, 1084-1093. [CrossRef]

20. Nocek, J.E.; Steele, R.L.; Braund, D.G. Effect of mixed ration nutrient density on milk of cows transferred from high production group. J. Dairy Sci. 1985, 68, 133-139. [CrossRef]

21. Jung, G.W.; Jo, I.H.; Hwangbo, S.; Lee, S.H.; Song, H.B. Effects of different feeding systems on nutrient availability, nitrogen retention and blood characteristics in native or crossbred Korean black goats. J. Korean Soc. Grassl. Forage Sci. 2008, 28, 341-350. [CrossRef]

22. Choi, S.H.; Hawngbo, S.; Kim, S.W.; Sang, B.D.; Kim, Y.K.; Jo, I.H. Effects of total mixed ration with wet brewer's grain on the performance and nutrient utilization in castrated Korean black goats. J. Korean Soc. Grassl. Forage Sci. 2006, 6, $199-206$.

23. Kim, D.I.; Choi, J.R.; Cho, S.H.; Lee, D.H.; Chung, T.Y. Effects of supplemental vegetable oils on ruminal characteristics, digestibility and formation of fatty acid soaps in sheep. J. Anim. Sci. Technol. 2004, 46, 783-798.

24. Chalupa, W.; Vecchiarelli, B.; Elser, A.E.; Kronfeld, D.S.; Sklan, D.; Palmquist, D.L. Ruminal fermentation in vivo as influenced by long-chain fatty acids. J. Dairy Sci. 1986, 69, 1293-1301. [CrossRef]

25. Ikwuegbu, O.A.; Sutton, J.D. The effect of varying the amount of linseed oil supplementation on rumen metabolism in sheep. Br. J. Nutr. 1982, 48, 365-375. [CrossRef]

26. Kowalczyk, J.; Ørskov, E.R.; Robinson, J.J.; Stewart, C.S. Effect of fat supplementation on voluntary food intake and rumen metabolism in sheep. Br. J. Nutr. 1977, 37, 251-257. [CrossRef] [PubMed]

27. Sahlu, T.; Goetsch, A.L.; Luo, J.; Nsahlai, I.V.; Moore, J.E.; Galyean, M.L.; Owens, F.N.; Ferrell, C.L.; Johnson, Z.B. Nutrient requirements of goats: Developed equations, other considerations and future research to improve them. Small Rumin. Res. 2004, 53, 191-219. [CrossRef]

28. Garrett, W.N. Energy efficiency of beef and dairy steers. J. Anim. Sci. 1971, 69, 2168-2176.

29. Byers, F.M. Patterns and energetic efficiency of tissue growth in beef cattle of four breeds. In Proceedings of the 9th Symposium of Energy Metabolism of Farm Animals, Lillehammer, Norway, 12 September 1982; p. 330.

30. Laurenz, J.C.; Byers, F.M.; Scheelling, G.T.; Greene, L.W. Effects of season on the maintenance requirements of mature beef cows. J. Anim. Sci. 1991, 69, 2168-2176. [CrossRef] [PubMed]

31. Salah, N.; Sauvant, D.; Archimede, H. Nutritional requirements of sheep, goats and cattle in warm climates: A meta-analysis. Animal 2014, 8, 1439-1447. [CrossRef] 